\title{
Hyperspectral Surveying for Mineral Resources in Alaska
}

- Hyperspectral surveys provide information about bedrock and cover materials on the Earth's surface.

- Data collection is rapid and can be completed at different spatial scales from broad-regional to detailed hand-specimen scale.

- The surveys provide geologists with information on rock composition that can augment existing geologic mapping.

- The map distributions of mineral classifications also help economic geologists identify areas with mineral deposits.

\section{Background}

Alaska is a major producer of base and precious metals and has a high potential for additional undiscovered mineral resources. However, discovery is hindered by Alaska's vast size, remoteness, and rugged terrain. New methods are needed to overcome these obstacles in order to fully evaluate Alaska's geology and mineral resource potential. Hyperspectral surveying is one method that can be used to rapidly acquire data about the distributions of surficial materials, including different types of bedrock and ground cover. In 2014, the U.S. Geological Survey (USGS) began the Alaska Hyperspectral Project to assess the applicability of this method in Alaska. The primary study area is a remote part of the eastern Alaska Range where porphyry deposits are exposed. In collaboration with the Alaska Division of Geological and Geophysical Surveys, the University of Alaska Fairbanks, and the National Park Service, the USGS is collecting and analyzing hyperspectral data with the goals of enhancing geologic mapping and developing methods to identify and characterize mineral deposits elsewhere in Alaska.

\section{Kilometer to Micrometer Scales}

This project applies an integrated approach that combines spectroscopic measurements with field and laboratory-based geologic investigations. Hyperspectral data (also known as imaging spectrometer data) have been collected at the following scales: (1) regional, (2) outcrop, and (3) hand specimen. The regional airborne survey, conducted over two days, used the HyMap $^{\mathrm{TM}}$ sensor and provides spectral characterization of surface materials across an extensive area $\left(1,900\right.$ square kilometers $\left.\left[\mathrm{km}^{2}\right]\right)$ at 6-meter $(\mathrm{m})$ resolution (fig. 1). A ground-based outcrop-scale survey done with the HySpex ${ }^{\mathrm{TM}}$ sensor provides higher spatial resolution mineral mapping over a kilometer-scale hillside at 30 -centimeter $(\mathrm{cm})$ resolution (fig. 2). The most detailed data were collected at 500-micrometer $(\mu \mathrm{m})$ spatial scale on individual rock samples in the laboratory using Corescan's Hyperspectral Core Imager Mark III ${ }^{\mathrm{TM}}$ imaging spectrometer. Analyses of these measurements reveal complex spatial relations of minerals (fig. 3). Scanning electron microprobe and X-ray diffraction analyses of rock and soil samples are used to validate mineralogical and spectral interpretations of hand specimens. The hand specimen and outcrop results are used to improve interpretations of the regional hyperspectral dataset.

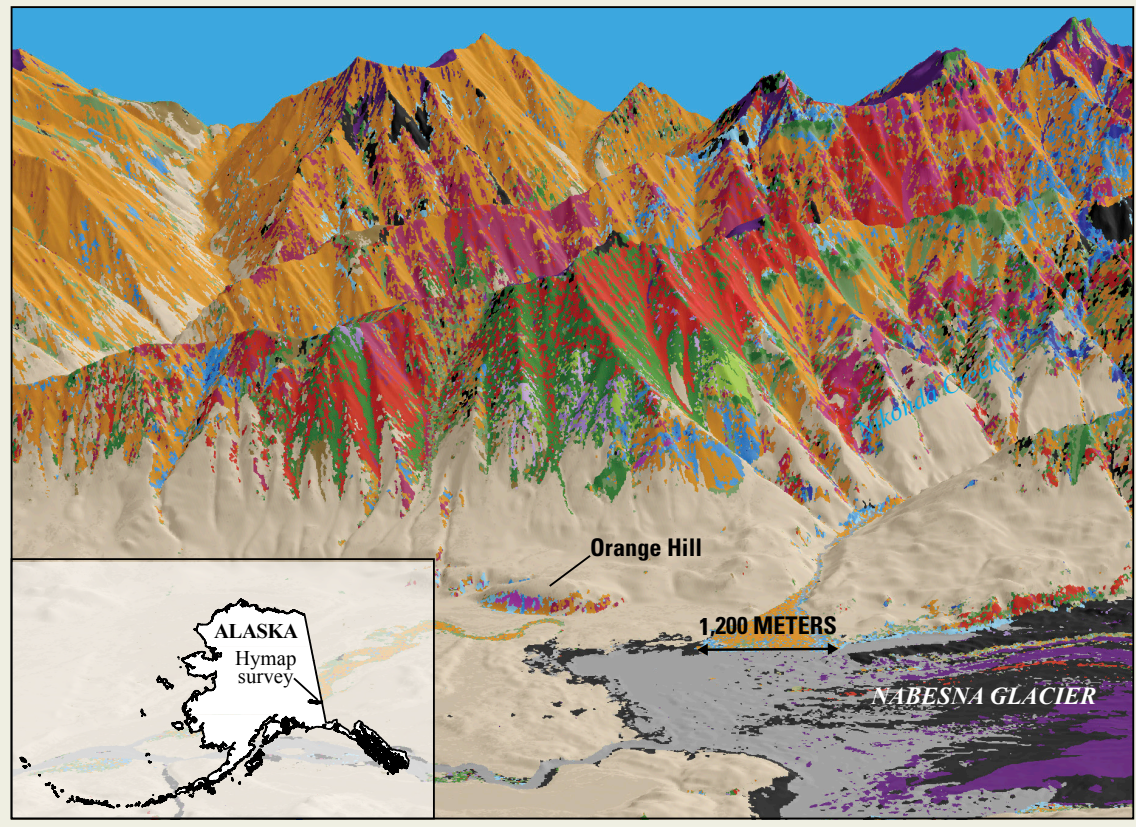

\section{EXPLANATION}

Material class names

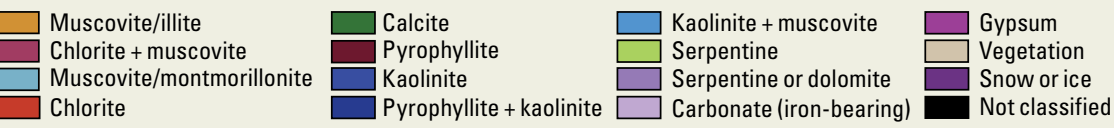

Figure 1. Regional mineral classification map overlaying a digital elevation model of the Orange Hill area, Wrangell-St. Elias National Park and Preserve, Alaska. Colors represent the spectrally dominant minerals. Data collected at 6-meter spatial resolution.

\section{What is hyperspectral analysis?}

When light hits a material, some of the light is reflected back from the material. Scientists measure the intensity of reflected light with a spectrometer. Measuring over a range of wavelengths generates a spectrum. The shape of the spectrum is like a fingerprint that provides information, including presence and qualitative abundance of certain minerals and the mineral chemistry. Some common minerals, such as quartz and feldspars, do not have distinctive sharp absorption features in the wavelength region of sunlight and must be detected with a thermal spectrometer.

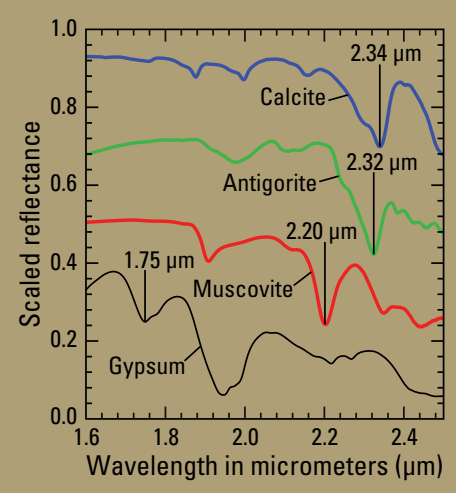

Example spectra in the 1.6- to 2.5-micrometer wavelength region showing diagnostic absorption features (dips) for calcite, antigorite, muscovite, and gypsum. 


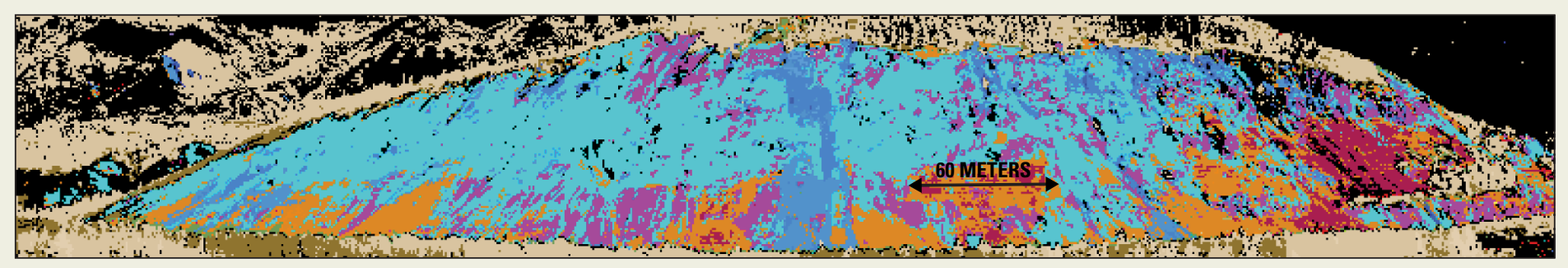

\section{EXPLANATION}

Material class names

Muscovite/montmorillonite $\square$ Kaolinite+muscovite $\square$ Muscovite/illite $\square$ Gypsum $\square$ Chlorite+muscovite $\square$ Chlorite $\square$ Vegetation $\square$ Not classified

Figure 2. Outcrop mineral classification map of the western side of the Orange Hill porphyry copper deposit. This mineral map was generated from data collected using a HySpex ${ }^{\mathrm{TM}}$ spectrometer. Note the different colors that indicate a predominance of clays, muscovite, and gypsum (likely related to porphyry mineralization) across the hillside. Data collected at 30-centimeter spatial resolution. Compare to the regional survey in figure 1.
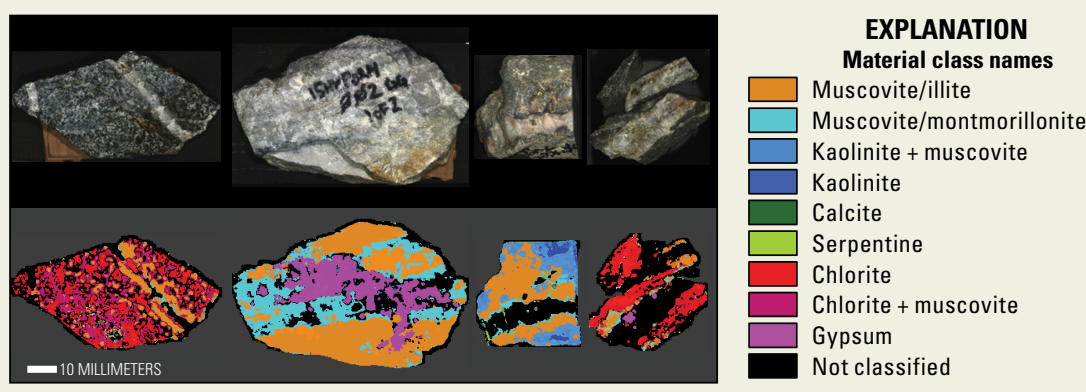

Figure 3. Hand specimen photograph (top) and mineral classification map (bottom) from Corescan ${ }^{\mathrm{TM}}$ data collected at the Orange Hill deposit. Data collected at 500-micrometer spatial resolution.

\section{Dominant Minerals and So Much More}

The hyperspectral surveys provide key pieces of information. Mineral classification maps (figs. 1-3) are based on a match to USGS spectral library standards (Clark and others, 2007) and show the predominant mineral(s) for each spectrum. The USGS is taking steps to extract even more information from the spectral data by developing methods to determine qualitative abundances of the predominant mineral(s) across the survey area. Subtle changes in the shapes of spectral features are also being examined to map differences in the chemical composition of select minerals. Generally, relative abundances of predominant mineral(s) and observed compositional differences of some minerals may reflect variations in rock type. In this study area, muscovite spectral features are empirically observed to change with proximity to porphyry copper deposits (fig. 4), as has been shown by studies in other areas (for example, Harraden and others, 2013; and Laakso and others, 2015).

\section{Preliminary Observations}

- Regional-scale mineral classification maps generally show lithologic changes consistent with previous geologic mapping.

- Mineralogical groupings are consistent at the regional $(6 \mathrm{~m})$ to outcrop scales $(30 \mathrm{~cm})$, with greater detail at the hand-specimen scale $(500 \mu \mathrm{m})$.

- Differences in wavelength positions for muscovite (different chemistry) can correspond to certain geologic units and general proximity to known porphyry occurrences.

- Preliminary observations in this study support past studies which indicated that hyperspectral data can be used as a tool to identify surface signatures of undiscovered mineral resources.

By Raymond F. Kokaly, Garth E. Graham, Todd M. Hoefen, Karen D. Kelley,

Michaela R. Johnson, and Bernard E. Hubbard

For more information, contact:

U.S. Geological Survey

Director, Crustal Geophysics and Geochemistry Science Center

Box 25046, MS 973 Denver Federal Center

Denver, CO 80225

http://crustal.usgs.gov

Any use of trade, firm, or product names is for descriptive purposes only and does not imply endorsement by the U.S. Government.

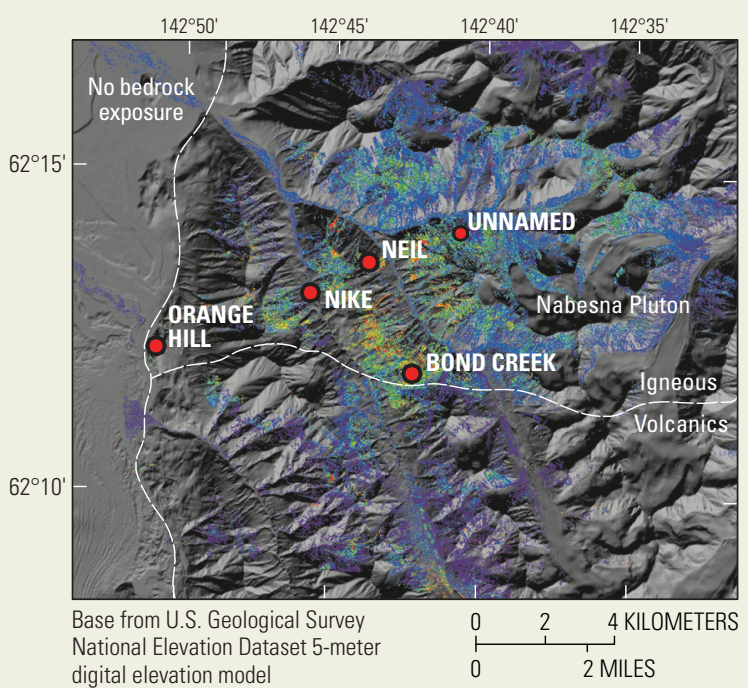

EXPLANATION

Wavelength position of muscovite feature (micrometer)

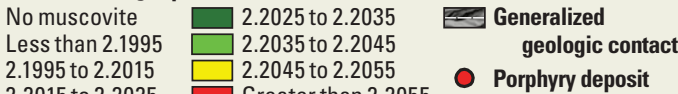
2.2045 to 2.2055

Figure 4. Orange Hill and Bond Creek areas showing systematic changes in wavelength position of muscovite. These changes are related to geology and proximity to porphyry deposits and occurrences.
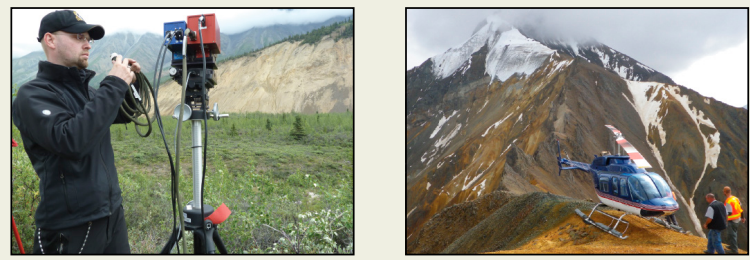

Field collections of hyperspectral data at Orange Hill (left) and geologic samples at Bond Creek (right).

\section{References Cited}

Clark, R.N., Swayze, G.A., Wise, R.A., Livo, K.E., Hoefen, T.M., Kokaly, R.F., Sutley, S.J., 2007, USGS digital spectral library splib06a: U.S. Geological Survey, Digital Data Series 231, http://speclab.cr.usgs.gov/spectral.lib06.

Harraden, C.L., McNulty, B.A., Gregory, M.J., and Lang, J.R., 2013, Shortwave infrared spectral analysis of hydrothermal alteration associated with the pebble porphyry copper-gold-molybdenum deposit, Iliamna, Alaska: Economic Geology, v. 108, no. 3, p. 483-494.

Laakso, K., Rivard, B., Peter, J.M., White, H.P., Maloley, M., Harris, J., and Rogge, D., 2015, Application of airborne, laboratory, and field hyperspectral methods to mineral exploration in the Canadian Arctic - Recognition and characterization of volcanogenic massive sulfide-associated hydrothermal alteration in the Izok Lake deposit area, Nunavut, Canada: Economic Geology, v. 110, no. 4, p. $925-941$. 